Article

\title{
Willingness to Comply with Corporate Law: An Interdisciplinary Teaching Method in Higher Education
}

\author{
Rafael Robina Ramirez ${ }^{1 \text { (1) and Pedro R. Palos-Sanchez }}{ }^{2, *}$ (1) \\ 1 Business Administration and Sociology, University of Extremadura, Avenida de la Universidad s/n, \\ 10071 Cáceres, Spain; rrobina@unex.es \\ 2 Business Administration and Marketing, University of Sevilla, Av. de Ramón y Cajal, 1, 41018 Sevilla, Spain \\ * Correspondence: ppalos@us.es; Tel.: +34-6706-35279
}

Received: 30 April 2018; Accepted: 4 June 2018; Published: 13 June 2018

check for updates

\begin{abstract}
Using an innovation training project, an interdisciplinary cross-sectional teaching strategy was developed to enhance students' willingness to comply with the law. Thirty-five business, finance and accounting teachers examined the effects of ethical education on 484 university students' willingness to comply with corporate law. Ethical education was based on building students' ethical decisions on three court judgments in the new Spanish Corporate Governance Code. The ethical training was carried out by developing and applying social justice counter arguments. This perspective allowed students to imagine what decisions other person could have taken if they had managed the company ethically. The results suggest that ethics education in higher education can improve the willingness to comply the law. This methodology can be applied to interdisciplinary departments teaching ethics in business, finance and accounting.
\end{abstract}

Keywords: comply with law; ethical education; willingness; business; finance and accounting; PLS; interdisciplinary; cross-sectional

\section{Introduction}

This paper examines how university students' attitudes enhance their willingness to comply with corporate law by improving their ethical decisions made in the light of the new Spanish Corporate Governance Code 1/2015 of 31 March (Spanish Corporate Governance Code 1/2015 of 31 March, retrieved from: https:/ / www.boe.es/boe/dias/2015/03/31/pdfs/BOE-A-2015-3439.pdf).

The recent Code requires companies to have mechanisms to comply with the laws, so that employer's reduce illegal conduct to in order to maintain people's professional and financial livelihoods [1], as well as to achieve justice and social inclusion for those producing goods and services [2]. Recent court judgments passed by the Spanish Supreme Court (154/2016, of 29 February 2016 and 221/2017, of 16 March 2017) condemn several companies for illegal business and financial acts, and for not having implemented special surveillance measures. Ever since the "corporate compliance" process was introduced, the results of these judgments have primarily been: economic penalties, claims for damages, loss of reputation, and loss of competitiveness [3,4].

Since the Spanish Code came into force companies have to implement effective organizational surveillance and monitoring systems with working mechanisms and standards [5]. They not only have to set up new corporate rules but also build willingness to comply with the law. However, it cannot be achieved by just imposing company rules, but ethical conduct must be promoted to managers, employees and large shareholders [6,7]. 
It is important to highlight that teaching compliance with corporate law is crucial in companies and also earlier on, in higher education [8,9]. It is in higher education where knowledge is first obtained about companies [10].

Personal success and profit maximization is highly regarded at business, finance and accounting faculties. However, there is hardly any teaching or training given which is concerned with increasing the willingness to comply with business regulations. Unfortunately, teaching compliance with the law by achieving high ethical standards at university are still far from being a reality [11]. It is not yet shown in university course programs [11]. It is not currently reflected at university programs [12]. It has been argued that current higher educational frameworks do not seems to find a model robust enough to teach compliance with corporate law by improving ethical conducts [13-15].

Doubts and concerns are being raised, especially in the area of business, finance and accounting, regarding the potential failure in developing students' awareness of compliance to the law [14-18]. It is not only because compliance with law and ethical behavior in those areas is the hardest part to be taught [19] but also because academics are not specialists in these areas of knowledge [20,21]. Therefore, more attention should be paid to compliance awareness among students at university in order to link personal behavior and social consequences to society [22].

With a multidisciplinary innovation training project, thirty-five academic staff from business, finance and accounting has incorporated the requirements of Spanish Corporate Law 1/2015 into a higher education program for the business, finance and accounting area. In other word, they have developed a methodology to overcome all the setbacks reported in the documentation [19-21] by examining the effects of ethical education on university students' willingness to comply with corporate law. The innovative approach represents a sustainable alternative to previous approaches. It provides a clear structure which can be applied without depending on leading key academic experts in ethics from philosophy or business ethics disciplines. The methodology is highly sustainable. It gives an essential tool to academics and students to insert ethics in their classes of accounting, finance and business, overcoming most of the problems raised up to this moment. The hypotheses proposed for this study were:

1. H1-Ethical Education received in 2015 impacts positively on students' Willingness to Comply with the Law in 2015.

2. H2-Ethical Education received in 2015 impacts positively on the Ethical Education received in 2016.

3. H3-Ethical Education received in 2016 impacts positively on students' Willingness to Comply with the Law in 2016.

4. H4-Ethical Education received in 2016 impacts positively on the Ethical Education received in 2017.

5. H5-Ethical Education received in 2017 impacts positively on students' Willingness to Comply with the Law in 2017.

6. H6-Willingness to Comply with the Law in 2015 impacts positively on Willingness to Comply with the Law in 2016.

7. H7-Willingness to Comply with the law in 2016 impacts positively on Willingness to Comply with the Law in 2017.

8. H8-Ethical Education received in 2015 impacts positively on the Ethical Education received in 2017.

9. H9-Willingness to Comply with the Law in 2015 impacts positively on Willingness to Comply with the Law in 2017.

In this period, a cross-sectional interdisciplinary teaching strategy was created to enhance the willingness to comply with the law using three case studies. Three court judgements were chosen from the Spanish Code for the academic project. These legal cases helped students and teachers to reflect on the ethical decisions students have to make to avoid the legal punishment of sentenced employers. 
In the teaching program, students were encouraged to individually consider ethical behavior by developing and applying social justice counter arguments [6,7]. The aim was to find socially valued outcomes to continuing working for the organization in a positive way. business, finance and accounting academics also took part in these training activities. Rest's four steps [23] were used as the fundamental knowledge needed by students to guide the ethical decisions which were made. These steps are moral sensitivity, moral judgment, moral motivation and moral character

The main contribution to the literature is threefold: (1) propose an interdisciplinary cross-sectional teaching methodology to allow academics to analyze court judgments from an ethical perspective. It provides a framework in order to take ethical decisions on illegal acts. (2) Enhance the willingness to comply with the law by highlighting the socially valued outcomes of the decision which are made. (3) Propose a methodology that can be used by other academic staff members in the business, finance and accounting area.

A longitudinal study was made using Smart PLS on the data collected [24]. Four hundred and eighty-four university students participated in the study. The same students from different courses participated every year so that the evolution of their answers could be analyzed yearly. The findings have important implications for university studies: (1) Understanding how illegal conduct can damage not only the company but the stakeholders are fundamentally important in studies of ethical decisions. Thus, our results offer important academic implications and useful insights that can be applied to management education. (2) Likewise, this investigation adds to current literature by providing new findings on how to incorporate the recent Spanish Corporate Governance Code into university programs for ethics education in business, finance and accounting $[8,9]$.

The paper is structured as follows: First, the current corporate compliance in companies is reviewed by implementing special control and surveillance policy measures. Second, this compliance can be applied by building a culture of respect for the law using the ethical decision-making process. Third, the main component of the ethical decision-making from social perspective is studied. Fourth, Smart PLS is used to study the variables and constructs from the data collected between 2015 and 2017. Finally, the results, conclusions and the implications of our findings in further research are stated.

\section{Literature Review}

\subsection{The Organizational Rules of Corporate Law}

With the worldwide economic crisis, complying with companies' regulations, ethical norms, and contracts has gradually become more difficultdue to the pressure of reducing wages, job losses and non-wage benefits putting increased pressure on employees [25]. Thishas also led to a very difficult climate for business, which puts pressure on managers and employees to achieve the goals set by company management [26-28].

This pressure has sometimes led to illegal behaviour as a means of achieving the company's objectives. It creates an environment in which the company balances on the borderline of legality $[29,30]$ in which employees' salaries and incentives depend directly on achieving the goals set by management. To obtain greater benefits some illegal actions are taken, such as: tax fraud, misrepresentation of the company's accounting records to obtain bank financing, and practices outside the principles of the free market system [31-33].

On a global level, a variety of economic policies have emerged in recent years to encourage compliance with corporate law, involving not only managers and employees but also shareholders and clients [34].

Law reinforcement measures on economic matters have led to the criminal liability of corporate legal representatives. It is in the Explanatory Memorandum of the Spanish Corporate Governance Code 1/2015 of 31 March, in which the amendment of the Criminal Code underlines the mechanisms that companies should incorporate to prevent economic crimes (Article 31bis, Compliance Law). The company can be held responsible in cases of environmental crimes, disclosure of secrets, intellectual 
or industrial property, international transactions, fraud, punishable insolvency, money laundering, the Public Treasury and Social Security, the rights of foreign citizens, computer damage, etc.

A managers' obligation to adopt and execute effective models of surveillance and control for the prevention of crimes are based on those rules as well as on ethical behavior. The compliance officers for these models can be an internal body or outsourced and must report on these matters. There seems to be consensus that the compliance officers should be legally representative and be composed of a group of people with knowledge on different subjects (criminal law, regulations and ethics).

\subsection{From Compliance with the Law to Ethics in Decision-Making}

Compliance with the law cannot be achieved by just imposing what is required in the rules. Ethics also have an important part in the decision making process. Willingness to comply with the law in an ethical way must be reinforced in companies by introducing ethical codes [35], promoting standards of behavior [36] and using ethical decision-making [23].

This means that not only the members of the internal body should have adequate ethical knowledge, but the employees too. These ethical rules must be applied in a participatory way, so that they are adhered to [37] and ethical decision making is promoted and accepted in the company [38]. Some cases of unethical activities in companies are (1) producing business reports in which information is hidden, in order to gain an advantage over competitors, and (2) launching advertising campaigns that do not really represent the product or service offered. Such unethical behaviour may not result in a legal sanction but could lead to the deterioration of a company's image by allowing unethical conduct.

To ensure that these cases do not occur in a company, the internal monitoring standards must go beyond just complying with the law [35]. Compliance programmes need to include an ethical decision-making process to enhance willingness to comply with the law in a company. Therefore, ethical decisions should be more than going "beyond compliance". They must also include ways to increase compliance standards from an ethical point of view. There are already countless examples of genuinely effective regulatory regimes with ethical training policies as models of how companies (often in cooperation with NGOs and government or intergovernmental agencies) can achieve standards above and beyond those required by law [39].

While surveillance models and ethical decisions help companies to comply with the law in economic matters, they are hardly mentioned in Higher Education programs. The current academic programs for business, finance and accounting pay very little attention to ethical matters and compliance with the law [12]. There are two reasons for this: Firstly, business, finance and accounting lecturers often don't do not feel professionally prepared in this area [21]. Secondly, academic courses are more likely to focus on self-interest [40] than on compliance awareness using ethical methods. Therefore, it is not surprising to find that many students are willing to compromise ethical principles in the interest of personal success [41].

Our proposal does not use a standard vertical teaching approach [42-44]) but a cross-sectional one instead [45]. This means that instead of teaching philosophical principles $[46,47]$ with individual, specialized seminars [20] or courses [48-50], willingness to comply with the law is included in the material in each separate subject. This cross-sectional methodology allows a culture of compliance to be created by not only studying the legal aspects, but by also analysing the ethical consequences of wrong decision-making.

Teaching ethical decision-making at university has great potential for shaping future the behavior of business and accounting professionals [37,51]. It plays a key role in improving civic conduct and professional responsibility of future graduates [52].

\subsection{The Four Steps of Decision-Making}

Ethical decision making is considered an ongoing process because a person has an ethical problem until different steps have been taken to overcome it [12]. Despite the variety of models available for the 
decision making process, there is consensus in the literature $[7,18]$ to include Rest's four steps: moral sensitivity, moral judgment, moral motivation and moral character [23].

A desire to comply with the law results from the moral sensitivity of students, which raises the students' awareness about a moral problem. A court judgment is used, which clearly expresses the illegal acts committed by a sentenced employer. Academic staff then explains to the class which articles of the law have been violated and then students discuss the moral problems created by those illegal acts.

Moral sensitivity helps students to be aware of two important points: firstly, that an employer's behavior will have an impact on other people by either harming or helping them. Secondly, that there are several options that can be chosen to avoid the problem [13,53]. These two characteristics imply that individuals see themselves as moral entities [13]. Rest highlights that moral sensitivity involves imaginatively constructing possible scenarios and applying empathy and role-taking skills.

The second component is moral judgment, in which students consider the 'good' and 'bad' points of each act. Moral judgments, as part of moral reasoning [54] helps student to clearly assess what 'ought' to be done in a particular situation [55]. This method helps students' attitudes and abilities to face future social and economic corporate problems, as well as linking action-based pragmatic teaching with ethical reflection [56]. According to [23], moral judgment defines which action is most morally justifiable and identifies a line of action as right or wrong. Students must study the context in which a court judgment was taken, in order to make a moral decision about it.

The third component, moral motivation, is how willing a person is to take a moral course of action, placing moral values above others, and taking personal responsibility for moral outcomes [57]. Moral motivation is the capacity to express values when managing a company. Moral motivation might increase willingness to comply with the law in two situations:

(1) In a self-evaluation process of "self-awareness and self-representation" [58] and similarly "self-reflection and self-evaluation" [59]. The self-evaluations should, in theory, induce the wrong-doer to solve any problem right at the start of the process, promoting moral decision-making and behavior [60].

(2) Considering the social representation of oneself in society and judging a company's level of perceived fairness [61] and whether the company conforms to social standards of fairness [58]. Haidt [62] proposed that people who see exemplary moral behavior of others react automatically, responding with positive moral conduct. More recently, Xie, Bagozzi, and Grønhaug [63] showed that positive individual business activities influence actions in the whole organization. Both considerations above help to ensure that ethical actions are taken [64,65], and that people behave in personally and socially appropriate ways [66].

The importance of regulating social conduct has been studied in previous research on companies and business $[67,68]$.

Finally, the fourth component of decision-making is moral character, which involves choosing and implementing certain behavior [23]. However, getting from moral intention to moral action is not always easy. Members of an organization can feel that they have previously taken illegal or unethical actions, which caused harm not only to the company but also to the employees. Moral character also includes increasing willingness to correct the damage they may have been previously caused, by increasing transparency, finding collaborative solutions, and promoting changes in standards and/or policies.

In the case study used in the classroom, students must consider not only the harm caused for the company and its employees, but how repeating the mistakes can be prevented, and minimizing any difficulties or challenges that may exist for taking the right action $[23,53]$. Such difficulties may include using instrumental coping responses after carrying out an unethical action and seeing how an organization performs effectively after the action. These strategies can help to overcome the intense unpleasant feelings associated with taking unethical behavior. 


\subsection{Decision-Making for Social Justice}

Over the last decade, deontologism or utilitarianism $[69,70]$ in several fields has proposed different ways to improve the willingness of the people to comply with the law by promoting ethical conduct. These theories want to establish universal principles or rules to evaluate moral human behavior.

With regard to the recent corporate compliance measures introduced in the Spanish Government Code, current corporate law describes rules that every company needs to abide by to avoid economic and administrative punishment.

In the context of this corporate law, deontological ethics is related to the current research in two specific points. First, deontologism needs to be applied by the compliance officer by following all relevant laws, rules, policies, regulations and standards, and ensuring that organisations adhere to all applicable legal requirements and by having a set of codes of conduct. This ethical perspective must be known to able to apply the rules of surveillance in the company. Second, based on the previous point, companies need to build confidence between the employer or boss and the employees in order "to promote a culture of respect towards the law" (Supreme Court, 20 February 2016).

Although these codes are not yet practiced routinely in companies, they are indeed models for cooperation between the operational processes of the organization and its management. They are also a point of orientation for professional action and legal evaluation. Employees should be guided towards the right ethical behaviour in such a way that they know how to behave in ambiguous situations. That is why deontologism is well-aligned with this research proposal.

However, establishing general guidelines should also be associated with strength then immoral character, which means choosing and using appropriate behavior [23]. Knowledge, skills and attitudes must be offered to individuals to allow them to correctly perform their corporate duties. In other words, correct conduct in a company depends on the employees' ability to perform it.

In European higher education, which establishes the structure of university education and university degree studies, the Spanish Royal Decree 55/2005, 21st of January, pointed out the need to combine basic general knowledge and general competencies. These are needed to gain skills, abilities and knowledge in every subject [71].

One of the general competencies is moral competence. Moral competence is considered to be closely related to moral virtue. As [72] states, when talking about leadership, moral competencies are nothing other than virtues which provide an example and promote the trust and willingness of people to follow a leader. This means that moral competence is a virtue which increases good conduct in a social context.

Morally responsibility can be seen to be important for what is seen to be best for the public as a whole. It has been linked to social competence and reasoning when improving social justice [73]. Social justice for others not only shows how willing a person is to act correctly in a society that has certain moral rules but to accept responsibility for their actions in a professional community or work group.

Individuals who feel strongly about other peoples' wellbeing will tend to maximize benefits for others in society [74]. Moreover, social justice increases a person's willingness to strive for correct actions that improve conditions for people in a society [75]. It also helps employees to use ethical behavior in a professional context.

This behavior has to be compared with the law. Usually, behaviors accepted by lawful procedures is likely to have ethical consequences for society, businesses and employees. Similarly, acts prohibited by law are most likely to have unethical consequences such as; crimes or misdemeanours in the fields of the Spanish Criminal Code (theft, murder, assault, rape, bribery, etc.) or administrative offences (lack of required licences or permits to build or open a business, failure to observe safety standards, etc.).

Nevertheless, when the law is clearly unjust towards people's dignity, the safety of a territory or its people, putting them in a risky situation. In this case, ethical behaviour could lead to refusal to obey the law. Following the argument, acts prohibited by law are not always synonymous with unethical consequences. For example, certain humanitarian circumstances are likely to have different legal 
consequences, creating a distance between ethical and legal perspectives. This is because "morality" and "legality" do not coincide in what concerns their formal approach.

Moral competence can be seen to influence decision-making to reach socially valued outcomes so that an organization is valued in a positive way.

For court judgments where employers have been sentenced for committing illegal acts, social justice provides guidelines for how to act in morally difficult or challenging situations [76]. It also proves useful when explaining different social behavior [77]. Past research has shown that people who strongly endorse social values have stronger personal moral rules and intentions to protect others [78] and the environment [79]. Those feelings were built on concepts of social justice when considering different situations and outcomes from different perspectives.

\section{Methodology}

\subsection{Stages in the Study}

Perspective changing techniques are used in ethical education by developing and applying social justice counter arguments so that ethical decisions can be made. This method allows students to imagine what decisions on social matters other people would take [73]. This method is somewhat similar to role changing, which is one of the basic concepts of moral judgment [80]. In these types of exercises, students are asked to identify: (1) what decisions students must take to avoid the sentence given in the court judgment. (2) Describe how those ethical decisions can affect the company's efforts to create social justice. Laws are not blindly accepted, but rather scrutinized by students to ensure social benefits (i.e., by identifying what is best for society as a whole), which is particularly relevant to moral judgment in organizations.

Twenty court judgements on employer's illegal behaviour were initially selected for students to analyse and to find ethical solutions. From these twenty, three were finally selected for the case studies in 2015, 2016, and 2017. The criteria for selection included: (1) the judgment must be for a common, representative case that Spanish citizens can recognize. (2) the size of the judgment. The text should not exceed 15 pages to ensure that students can read and analyze it in class or at home. (3) Nondiscriminatory. The content of the judgment should not include statements that could be regarded as discriminatory about race, social matters, religion, etc.

The educational stages and exercises were prepared in six meetings about education in ethics for students. The meetings were held over a period of two months. The project was divided into ten different stages: (1) training activities on "ethical commitment"; (2) selection of the court judgments to be studied; (3) study of the court judgment by the teachers; (4) analyzing the illegal acts and their meaning in order to build ethical conducts from those illegal acts; (5) making an ethical decision for the judgment to minimize the social consequences for the employee, company or stakeholders; (6) preparing a questionnaire for the project and testing it on the students; (7) organizing four meetings with the students to explain the legal terms needed in the case study, to distribute the cases to the students, to hear the students' ethical decisions on the illegal acts, and to register the students' opinion son compliance with law; (8) data tabulation; (9) presenting the study to students and the Innovation Project manager; and (10) holding a meeting with teachers to assess the results.

\subsection{Hypotheses Model for the Study}

Several hypotheses were proposed to measure the impact of students' ethical education on their willingness to comply with the law and the evolution of this willingness over time (see the variables between 2015 and 2017, see Figure 1). It was decided to analyze the hypotheses using structural equations modeling (SEM) with partial least squares (PLS). The reasons for this choice were the research objectives, the quality of the theoretical framework and the exploratory objectives of the study [81]. Usinga Smart PLS longitudinal study, the exogenous and endogenous constructs were measured at different moments in time [82-84]. 


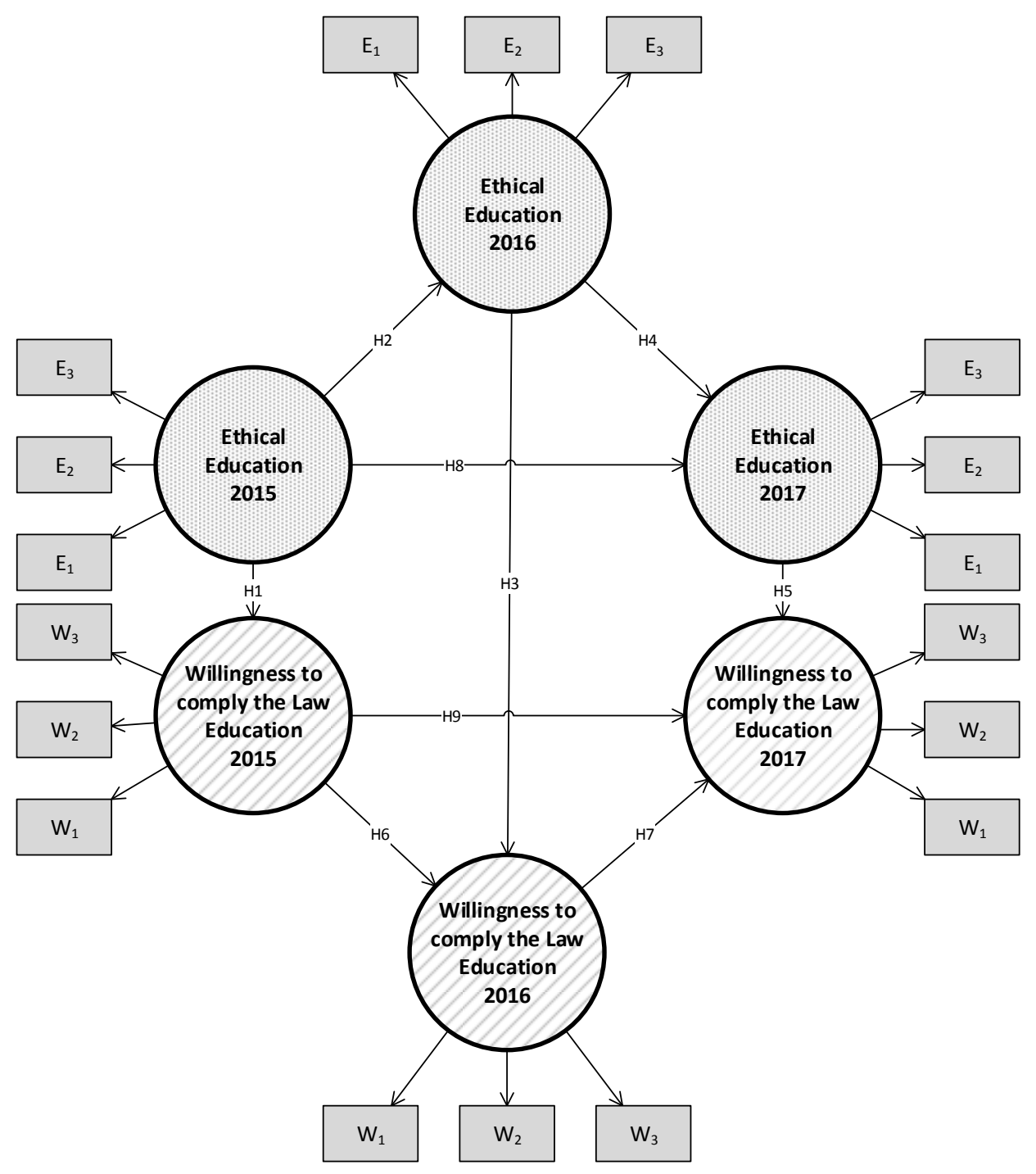

Figure 1. Improving the ethical education in higher education for business, finance and accountancy.

\subsection{Ethics Education Training}

The activities to improve the willingness to comply with the law are grouped into several steps: First, each year a court judgment was selected by the multidisciplinary research team from commons incidents in Spanish companies. The judgement was chosen using the following criteria:

1. Business or Finance content of the judgment. It must represent a recognizable case for citizens throughout Spanish society.

2. Extension of the judgment. The "issues of fact" should not exceed 10-15 pages to ensure the students can read it in class or at home.

3. Nondiscriminatory. The content of the judgment should not include statements that could be regarded as discriminatory behaviour based on race, social matters, religion, etc.

A summary of the cases is provided in Table 1. 
Table 1. Court judgments' contents.

\begin{tabular}{|c|c|c|}
\hline Year & Court Judgement & Court Judgement Summary \\
\hline 2015 & $\begin{array}{l}\text { Provincial Court of Madrid, } \\
\text { Section 6, Judgment } 490 / 2000 \text { of } \\
28 \text { November 2000, Rec. 85/1995 }\end{array}$ & $\begin{array}{l}\text { A person sets up a group of security services and urgent } \\
\text { courier companies. As the sole administrator of the } \\
\text { companies, he defines the social and fiscal guidelines } \\
\text { independently of the administrative body. This council } \\
\text { consisted of people from his own family circle-wife, } \\
\text { children, sons-in-law, etc. Neither the company accounts } \\
\text { nor the operations were reported for } 5 \text { years. } \\
\text { Tax obligations were not upheld and the tax declarations } \\
\text { were modified in order to pay fewer taxes to the Public } \\
\text { Treasury. The administrator also defrauded the } \\
\text { Public Treasury. }\end{array}$ \\
\hline 2016 & $\begin{array}{l}\text { Provincial Court of Córdoba, } \\
\text { Section 3, Judgment 318/2015 of } \\
29 \text { June 2015, Rec. 17/2014 }\end{array}$ & $\begin{array}{l}\text { The defendants, by mutual agreement and guided by illicit } \\
\text { enrichment, drafted contracts that reflected non-existent } \\
\text { operations of olive sales to ensure that the business profits } \\
\text { of one company went to another, to the detriment of } \\
\text { the first. }\end{array}$ \\
\hline 2017 & $\begin{array}{l}\text { Provincial Court of Barcelona, } \\
\text { Section 8, Judgment of } 5 \text { July 2016, } \\
\text { Proc. 110/2015 }\end{array}$ & $\begin{array}{l}\text { Malicious hiding of relevant fiscal data. Omission of } \\
\text { declarations and avoidance of income tax payment on } \\
\text { income received for the exploitation of image rights. } \\
\text { Transfer of contractual rights using companies based in } \\
\text { countries whose tax legislation allows opacity, constituting } \\
\text { an "offshore" network with which the public treasury was } \\
\text { defrauded of more than } 4 \text { million euro. }\end{array}$ \\
\hline
\end{tabular}

Second. Students in Business, Finance and Accounting courses are not totally familiar with the legal terms used in business issues. Even though legal obligations are derived from moral obligations rooted in beliefs, values and attitudes the meaning of the legal articles had to be explained to the students. Table 2 shows the legal concepts contained in each court judgement, which were explained to teachers and students by a law expert.

Table 2. Definitions of the legal articles.

\begin{tabular}{|c|c|c|}
\hline Year & Court Judgement & Legal Article \\
\hline 2015 & $\begin{array}{l}\text { Provincial Court of Madrid, } \\
28 \text { November 2000, Rec. 85/1995 }\end{array}$ & $\begin{array}{l}\text { Felonies against the Social Security. } \\
\text { Accounting crime: notkeeping corporate accounting or tax } \\
\text { nor obligatory bookkeeping. } \\
\text { Concealing or inventing the true position of the business. } \\
\text { Fraud or swindling. }\end{array}$ \\
\hline 2016 & $\begin{array}{l}\text { Provincial Court of Córdoba, } \\
29 \text { June 2015, Rec. 17/2014 }\end{array}$ & $\begin{array}{l}\text { Falsifying annual accounts and another documents. } \\
\text { Misappropriation or stealing money, belongings, valuables } \\
\text { or any personal property received in deposit, in trust or } \\
\text { administration. } \\
\text { Forgery of official and business documents. }\end{array}$ \\
\hline 2017 & $\begin{array}{l}\text { Provincial Court of Barcelona, } \\
\text { July 2016, Proc. } 110 / 2015\end{array}$ & $\begin{array}{l}\text { Felonies against the Social Security to defraud the state, } \\
\text { regional or local treasury. }\end{array}$ \\
\hline
\end{tabular}

Third, students analysed how the articles were violated in the case study (see Table 3). 
Table 3. Legal articles violated in the three case studies.

\begin{tabular}{|c|c|c|}
\hline Year & Articles & Legal Articles \\
\hline 2015 & $\begin{array}{l}\text { Art. } 310 \text { and } 74 \text { Penal Code., } \\
\text { On felonies against the } \\
\text { Social Security } \\
\text { Art. } 349 \text { and } 248 \text {. On fraud }\end{array}$ & $\begin{array}{l}\text { Felonies against the Social Security; Continued } \\
\text { accountancy crime: } 1 \text {. Keep corporate accounting, } \\
\text { bookkeeping or tax records. } 2 \text {. No record of the fictitious } \\
\text { accounting entries in the obligatory bookkeeping. } \\
\text { Fraud: Continued fraud crime: using deceit for profit, } \\
\text { to mislead another person so that they carry out an act in } \\
\text { their own detriment or that of another. Swindling. }\end{array}$ \\
\hline 2016 & $\begin{array}{l}\text { Art } 393 \text { (LAW 3996/1995) On } \\
\text { forgery of official and business } \\
\text { documents }\end{array}$ & $\begin{array}{l}\text { Corporate offences: } 1 \text {. Falsify annual accounts or other } \\
\text { documents that record the legal or financial status of the } \\
\text { company in such a way to cause financial damage thereto } \\
\text { or to any of its shareholders or partners. } \\
\text { Misappropriation: anybody who, to the detriment of } \\
\text { another, appropriate or steal money, belongings, valuables } \\
\text { or any other moveable or personal property that they have } \\
\text { received in deposit, in trust or administration. } \\
\text { Forgery of official and business documents: whoever uses } \\
\text { a forged business document to harm another knowing that } \\
\text { the document is forged by altering any of the essential } \\
\text { elements or requisites of the document. }\end{array}$ \\
\hline 2017 & $\begin{array}{l}\text { Art } 305 \text { (LAW 3996/1995) Crimes } \\
\text { against the Treasury Art. } 21.5 \text { C.P. } \\
\text { (LAW 3996/1995) On felonies } \\
\text { against the Social Security }\end{array}$ & $\begin{array}{l}\text { Felonies against the Social Security; Continued } \\
\text { accountancy crime: } 1 \text {. Any person who, whether by action } \\
\text { or omission, defrauds the state, regional or local treasury, } \\
\text { avoiding the payment of taxes or deductions, } 2 \text {. Any } \\
\text { person who defrauds any amount that should have been } \\
\text { deducted or likewise receiving fiscal benefits, provided } \\
\text { that the defrauded payment, the unpaid deductions, } \\
\text { credit payments, rebates or fiscal benefits were } \\
\text { wrongfully obtained. }\end{array}$ \\
\hline
\end{tabular}

Fourth, describe how companies and stakeholders can use ethical decisions to implement actions to avoid future illegal activities (see Table 4 ).

Table 4. Ethical decisions based on illegal behaviours.

\begin{tabular}{|c|c|}
\hline Year & Main Ethical Decisions \\
\hline \multirow{4}{*}{2015} & To have a yearly external audit of the company's money transfers. \\
\hline & $\begin{array}{l}\text { Investigate, promote and use innovative control processes to identify any hidden } \\
\text { cash-flow activities. }\end{array}$ \\
\hline & $\begin{array}{l}\text { Establish an incentive system to reward the ethical compliance with rules, culture } \\
\text { and codes of conduct. }\end{array}$ \\
\hline & $\begin{array}{l}\text { Every client will receive an identifiable, individual warranty of the use of the } \\
\text { above endorsements. }\end{array}$ \\
\hline \multirow{4}{*}{2016} & $\begin{array}{l}\text { To establish an agreed code of ethics for the profession based on the values expressed } \\
\text { by members. }\end{array}$ \\
\hline & To install a transparent system to publish the credit accounting information. \\
\hline & $\begin{array}{l}\text { 3. To invest in resources to improve internal controls and eliminate risks from sales } \\
\text { department errors. }\end{array}$ \\
\hline & Establish a transparent system to show the company debt rating. \\
\hline \multirow{3}{*}{2017} & $\begin{array}{l}\text { 1. To develop a fairer tax payment system because tax evasion depends on beliefs about } \\
\text { tax system fairness. }\end{array}$ \\
\hline & $\begin{array}{l}\text { 2. To advise on the reasons to pay taxes and promote contributing to society by } \\
\text { fulfilling government regulations. }\end{array}$ \\
\hline & $\begin{array}{l}\text { 3. To apply fraud prevention measures to any operations carried out by persons } \\
\text { affiliated by family, vicinity, community or business whose links must be analyzed } \\
\text { and evaluated. }\end{array}$ \\
\hline
\end{tabular}


Fifth, investigate how university students' ethical education enhances their willingness to comply with corporate law after the training activities. A questionnaire was used for this. Questions were organized into two, based on the information gathered from the literature review: 1. Ethical education. 2. Willingness to comply with the law (see Table 5).

Table 5. Questionnaire to measure the students' willingness to comply with the law.

\begin{tabular}{|c|c|c|}
\hline Latent Variables & Questions & Authors \\
\hline E: Ethical education & $\begin{array}{l}\text { Is it important for you to increase your knowledge and skills to link illegal acts with } \\
\text { ethical behaviour in oder to improve your compliance with the law? }\left(\mathrm{E}_{1}\right) \\
\text { Is it important for you to receive ethical training in all business, finance and accounting } \\
\left.\text { subjects in order to better comply with the law? ( } \mathrm{E}_{2}\right) \\
\text { Is the social aspect of ethical education relevant for you to better comply with the law in } \\
\text { order not to harm employees nor the company and its stake holders? }\left(\mathrm{E}_{3}\right)\end{array}$ & [8-10] \\
\hline $\begin{array}{l}\text { W: Willingness to comply } \\
\text { with the law using } \\
\text { ethical decisions }\end{array}$ & $\begin{array}{l}\text { Are you willing to take ethical decisions about employees, employers and } \\
\text { stakeholders? }\left(\mathrm{W}_{1}\right) \\
\text { Are you willing to improve yourself using ethical values to comply with the law? }\left(\mathrm{W}_{2}\right) \\
\text { Are you willing to improve society to better comply with the law in order to build a more } \\
\text { lawful society? }\left(\mathrm{W}_{3}\right)\end{array}$ & {$[18,53,85]$} \\
\hline
\end{tabular}

\section{Results}

\subsection{Measurement Model}

The structural equations model allowed analyzing the factorial loads of the variables or indicators. Initially, the individual reliability of each indicator was analyzed, that is, the simple correlations between indicators and their respective contruct. Then, an analysis of the individual reliability of the items was carried out observing the charges $(\lambda)$. According to [86], the minimum level for acceptance as part of the construct was established at $\lambda \geq 0.707$ (see Figure 2). Next the variance of the variables was found using the commonality, and the calculated value must be $\geq 0.50$. Reliability evaluates the internal consistency of the latent variables from these indicators and it was found by using Cronbach's alpha and the composite reliability (CR, Composite Reliability) of the construct [87]. Any values $<0.70$ indicate lack of reliability [88]. Table 6 also shows another indicator known as rho_A [89], for which all the constructs exceed 0.7 .

Table 6. Reliability, validity of the constructs and criterion by [89].

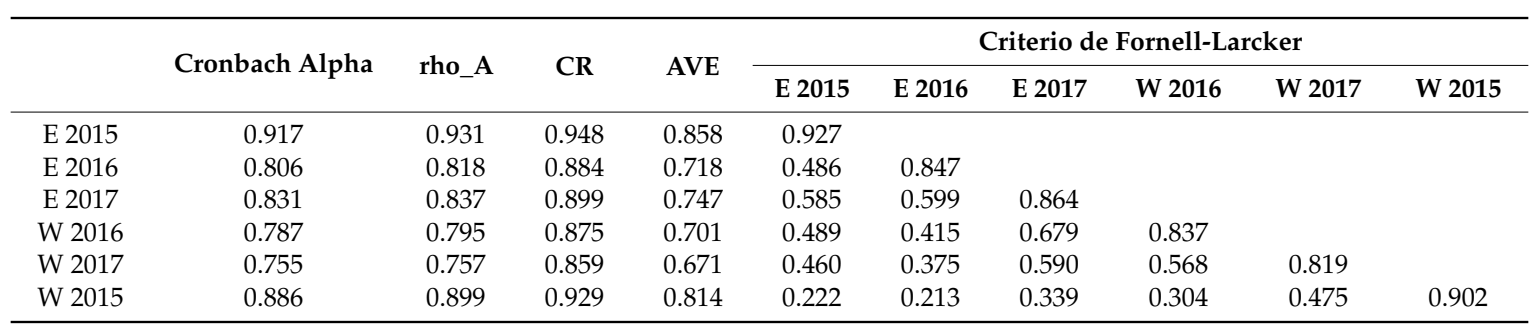

Convergent validity, calculated with (AVE), or average current variance [90] means that a set of items represents a contruct. As can be seen in Table 7, the criterion that this value must be higher than 0.50 is fulfilled, which means that at least half of the variance of those indicators can be explained [88]. Another criterion applied was that of [90] which involves verifying that the square root of the average variance extracted (AVE) is greater than the relation between the construct and the rest of the constructs of the model (see Table 6). 


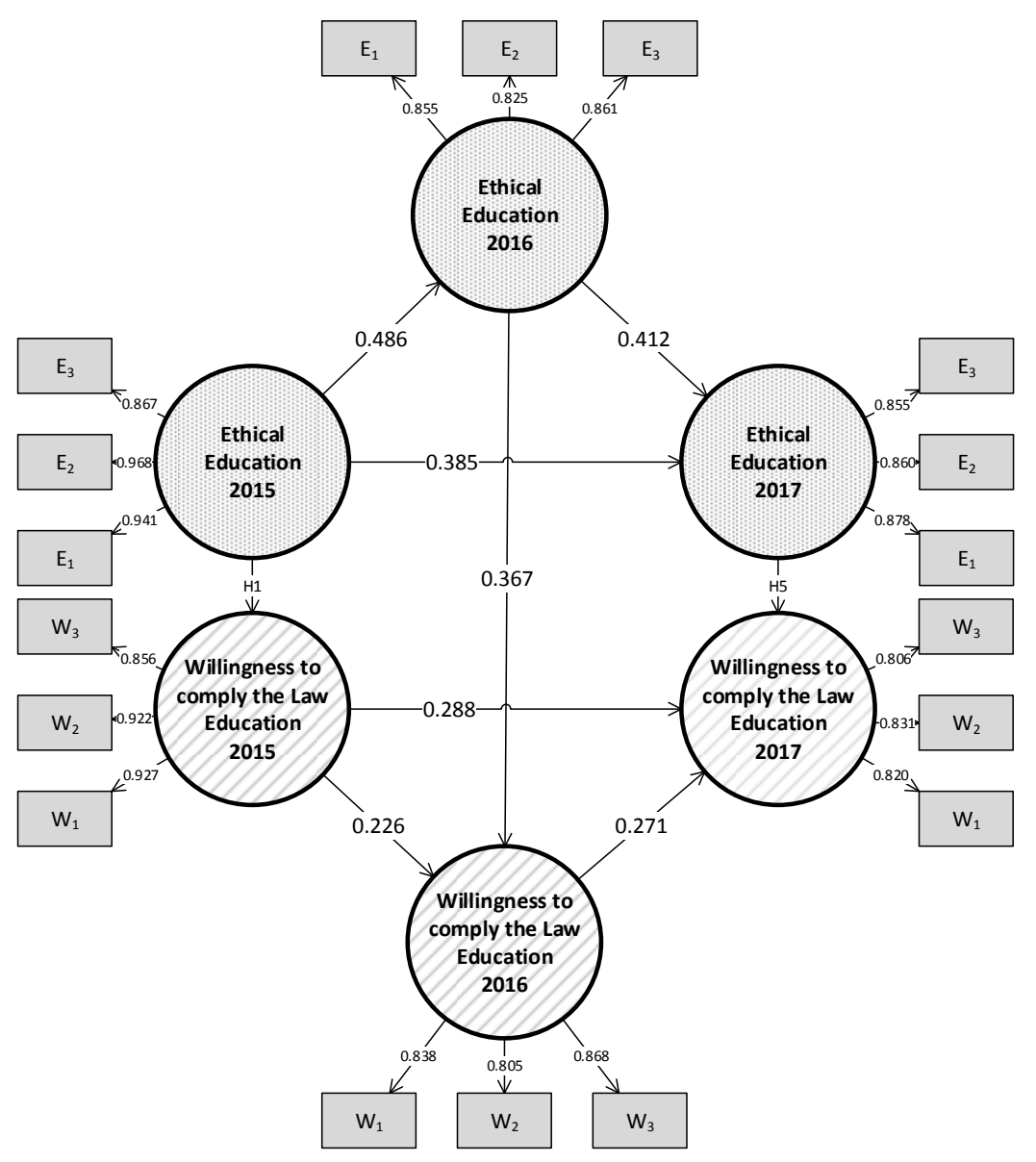

Figure 2. Resulting final PLS model.

Table 7. HTMT, $R^{2}$ y $Q^{2}$ results.

\begin{tabular}{ccccccccc}
\hline $\begin{array}{c}\text { Heterotrait-Monotrait } \\
\text { Ratio (HTMT) }\end{array}$ & E 2015 & E 2016 & E 2017 & W 2016 & W 2017 & W 2015 & $R^{2}$ & $\mathbf{Q}^{\mathbf{2}}$ \\
\hline E 2015 & & & & & & & & \\
E 2016 & 0.553 & & & & & & 0.236 & 0.156 \\
E 2017 & 0.663 & 0.717 & & & & & 0.472 & 0.330 \\
W 2016 & 0.569 & 0.513 & 0.830 & & & & 0.221 & 0.143 \\
W 2017 & 0.550 & 0.483 & 0.744 & 0.734 & & & 0.473 & 0.298 \\
W 2015 & 0.244 & 0.260 & 0.393 & 0.357 & 0.575 & & 0.049 & 0.037 \\
\hline
\end{tabular}

Fornell and Larcker [91] carried out simulation studies to demonstrate that the lack of discriminant validity is detected better with another technique, which is the heterotrait-monotrait ratio (HTMT). Table 7 shows the results obtained, where it can be seen that all the HTMT ratios for each pair of factors is $<0.90[92,93]$. The magnitude and importance of the relationships between the latent variables was calculated using the standardized Path coefficient. The rule established by Chin [94] states that the value must be at least 0.2 (see Figure 2). Fulfilling all these criteria and measures means that the validity and reliability of the model is ensured.

\subsection{Structural Model Analyses}

The following analyses were used to study the structural model, the explained variance of the endogenous constructs $\left(R^{2}\right)$, path coefficients $(\beta)$ and selection of critical values for the Student's $t$ distribution [95]. The approximate adjustment of the model $[93,96]$ is determined by the value obtained from the residual root mean square (SRMR) [97,98], which measures the difference between the 
observed correlations matrix and the implied correlations matrix of the model. Thus, the SRMR reflects the average magnitude of such differences and, the lower the SRMR, the better the fit. In our case SRMR $=0.062$ and is within the recommendation for a model with a good fit when SRMR $<0.08$ [97].

The explanatory capacity of the model is found by the value of $R^{2}$. Table 8 shows the results obtained for the endogenous constructs. Chin [94] explains that values for $R^{2}$ of $0.67,0.33$ and 0.19 can be considered strong, moderate and weak. In this study the results obtained show a greater variance explained for the constructs of year $2017\left(R^{2}\right.$ Ethical Education $=0.472, R^{2}$ Willingness to comply with the law $=0.473$ ), which represent moderate values with sufficient explanatory capacity.

Next, the model was analyzed using the nonmetric bootstrapping technique. In this technique the standard deviation of the parameters and the student's $t$ values are found. From these the simple regression coefficients are calculated for the components and the results for the relationships between the latent variables of the study hypotheses are calculated. The p-value, shown in Table 8 , is used to do this.

The results obtained (see Table 8) for the ethical education received by students positively influence the students' willingness to comply with the law, as the hypothese are supported in all the periods studied. H1 $(\beta 2015=0.222, p$-value $=0.000), \mathrm{H} 3(\beta 2016=0.367, p$-value $=0.000)$ and H5 $(\beta 2017=0.309$, $p$-value $=0.000)$. Similarly, the hypotheses relating ethical education with itself is also supported in the different years studied. H2 $(\beta 2015-2016=0.486, p$-value $=0.000), H 4(\beta 2016-2017=0.309$, $p$-value $=0.000)$ and H8 $(\beta 2015-2017=0.385, p$-value $=0.000)$. The willingness to comply with the law when related to itself is also supported in the years studied. H6 $(\beta 2015-2016=0.226, p$-value $=0.000)$, H7 $(\beta 2016-2017=0.271, p$-value $=0.000)$ and H9 $(\beta 2015-2017=0.288, p$-value $=0.000)$. Therefore, all the hypotheses are supported with a significance of 0.001 , which means $99.9 \%$ ( $p$-value $<0.001$ ).

The predictive relevance of the model was studied using the blindfolding procedure, in which part of the data for a given construct was omitted during the parameter estimation, and then the data that had been omitted was replaced using the estimated parameters [94]. In this way, the predictive relevance of the model was studied using the Stone-Geisser $\left(Q^{2}\right)$ test $[99,100]$, which revealed that the model is predictive $\left(Q^{2} W_{2017}=0.298\right)$ since $Q^{2}>0$ (see Table 7).

The results obtained and shown in Table 9 show an increase in some of the relationships over time. This observation is the result of the variation of the path coefficient of each construct in different periods. In all cases the variation from 2015 to 2017 was significant (see Table 8). To verify that this change is significant, the nonparametric confidence-set approach was used ${ }^{*} p<0.05 ;{ }^{*} p<0.01$; *** $p<0.001$; n.s.: not significance) [101]. This analysis consists of forming different groups that belong to different periods of time and carrying out a multigroup analysis on them $[88,101]$.

Table 8. Significance calculations for the hypotheses.

\begin{tabular}{|c|c|c|c|c|c|}
\hline Hypothesis & & $\beta$ (Path Coeff.) & $t$ Value & $p$ Value & Supported \\
\hline Hypothesis 1 & E $2015 \rightarrow$ W 2015 & 0.222 & 3.993 & 0.000 & Yes *** \\
\hline Hypothesis 2 & E $2015 \rightarrow$ E 2016 & 0.486 & 11.904 & 0.000 & Yes $* * *$ \\
\hline Hypothesis 3 & E $2016 \rightarrow$ W 2016 & 0.367 & 9.476 & 0.000 & Yes *** \\
\hline Hypothesis 4 & E $2016 \rightarrow$ E 2017 & 0.412 & 10.044 & 0.000 & Yes $* * *$ \\
\hline Hypothesis 5 & E $2017 \rightarrow$ W 2017 & 0.309 & 5.935 & 0.000 & Yes *** \\
\hline Hypothesis 6 & W $2015 \rightarrow$ W 2016 & 0.226 & 5.541 & 0.000 & Yes *** \\
\hline Hypothesis 7 & W $2016 \rightarrow$ W 2017 & 0.271 & 5.457 & 0.000 & Yes *** \\
\hline Hypothesis 8 & E $2015 \rightarrow$ E 2017 & 0.385 & 7.265 & 0.000 & Yes *** \\
\hline Hypothesis 9 & W $2015 \rightarrow$ W 2017 & 0.288 & 6.487 & 0.000 & Yes *** \\
\hline
\end{tabular}

Notes: ${ }^{*} p<0.05 ;{ }^{* *} p<0.01$; ${ }^{* * *} p<0.001 ;$ n.s.: not significance. 
Table 9. Significance test results.

\begin{tabular}{|c|c|c|c|c|c|c|}
\hline Effect & Path Coeff $(\beta)$ & Size of Change & Confidence Intervals (CI) & $\begin{array}{l}\text { Comparison of Path Coefficient } t+1 \text { with } \\
\text { CI } t \text { Andpath Coefficient } t \text { with CI } t+1\end{array}$ & $\begin{array}{l}\text { Path Coefficient } t+1 \text { Inside CI } t \text { ? } \\
\text { Path Coefficient } t \text { Inside CI } t+1 \text { ? }\end{array}$ & Significant Change? \\
\hline E $2015 \rightarrow$ E 2016 & 0.486 & \multirow[t]{2}{*}{-0.074} & $(0.404 ; 0.564)$ & $0.404<0.412<0.564$ & Yes & \multirow[b]{2}{*}{ No } \\
\hline E $2016 \rightarrow$ E 2017 & 0.412 & & $(0.321 ; 0.496)$ & $0.321<0.486<0.496$ & Yes & \\
\hline W $2015 \rightarrow$ W 2016 & 0.226 & \multirow[t]{2}{*}{0.045} & $(0.149 ; 0.310)$ & $0.149<0.271<0.310$ & Yes & \multirow[b]{2}{*}{ No } \\
\hline W $2016 \rightarrow$ W 2017 & 0.271 & & $(0.176 ; 0.372)$ & $0.176<0.226<0.372$ & Yes & \\
\hline E $2015 \rightarrow$ W 2015 & 0.222 & \multirow[t]{2}{*}{0.145} & $(0.126 ; 0.317)$ & $0.126<0.367$ & No & \multirow[b]{2}{*}{ Yes } \\
\hline E $2016 \rightarrow$ W 2016 & 0.367 & & $(0.291 ; 0.446)$ & $0.222<0.446$ & No & \\
\hline E $2016 \rightarrow$ W 2016 & 0.367 & \multirow[t]{2}{*}{-0.058} & $(0.291 ; 0.446)$ & $0.291<0.309<0.446$ & Yes & \multirow{2}{*}{ No } \\
\hline E $2017 \rightarrow$ W 2017 & 0.309 & & $(0.203 ; 0.401)$ & $0.203<0.367<0.401$ & Yes & \\
\hline
\end{tabular}


Table 9 shows the results of the significance test for the direct effects (relationships between different constructs) and whether there is a carry-overeffect in the path coefficients [84] to measure the relationship of a construct with $t+1$. This is found by comparing the path coefficients with CI (confiance interval) and checking if the coefficient is inside or outside CI. It is important to assess whether the change is significant.

The results in Table 9 show that only the direct effects exerted by E 2015 on W 2015 and E 2016 on W 2016 are significant in the time periods that were studied. These tests show that there are different ways of proving the importance of changes in the relationships (path coefficients) of constructs over time [83]. Likewise, it was shown that these relationships do not significantly weaken over time, and that carry-overeffects do not occur for the path coefficients.

\section{Discussion}

As has been mentioned in the paper, the aim of this study is to raise university students' awareness of the legal boundaries of their behaviour and the unethical behaviour linked thereto. Thus, students were asked to provide answers in relation to a real and objective situation that had occurred in some court judgements.

It is not easy to find a model in which all hypotheses are supported with a significance valueof 0.001 , or $99.9 \%$ confidence level. This means that theethical education received by students over the period of three years had a positive impact on their willingness to comply with the law. In other words, the interdisciplinary cross-sectional methodology used to enhance the students' willingness to comply with the law was effective.

The results have shown that this method of learning ethic, following the cross-sectional school of teaching ethic, is a relevant tool to study ethics in the Financial, Business and Accounting areas. Not only because students have become more aware of the consequences of unethical behaviour to the company, but also because they have been able to link illegal acts with the associated punishment, which helped them to comply with the law better.

Even though business, finance and accounting teachers may not be specialists in the areas of compliance and ethics [20,21] due to the difficulties they find teaching them [19] this study explains an acceptable method that can be used. By applying this open methodology over three years, university students increased their awareness of compliance with the law. The interdisciplinary team must be really vigilant and follow all the steps presented in the methodology.

First of all, research needs experts in psychology and law to lead every project's steps, once it is settled, this methodology can be followed by academics, who are not expert in ethics, in economic areas. So, the general significance of the study goes beyond the limited case population.

Moreover, the results obtained not only show a great variance in the constructs of the last year, $2017\left(R^{2}\right.$ Ethical Education $=0.472, R^{2}$ Willingness to comply with the law $\left.=0.473\right)$ but also a predictive relevance for the model $\left(Q^{2} W_{2017}=0.298\right)$ since $Q^{2}>0$. This means the relationship of ethical education on willingness to comply with the law over the three-year period was strongly supported and explained. Similarly, the ability to make reasonable predictions about willingness to comply with the law and the rest of the dependent variables over time was shown. This means the model not only identifies the important variables and constructs but can also help to make predictions about what students need to increase their willingness to comply with the law.

The current lack of training on ethical matters in academic programmes [12] means that this study can be used to fill this gap is four different ways:

(1) Cross-sectional methods for teaching ethical compliance with the law allowed the Teaching Innovation Group to build a compliance program including thirty-five subject areas. This goes beyond vertical proposals to teach ethics from only a few, specific subjects [42-44].

(2) With this methodology which connects law with ethical issues using court judgment, students can centre their attention on the crimes that most affect Spanish companies, such as failing to 
pay Social Security, accounting crimes, fraud, corporate offences, falsification of annual accounts, misappropriation, etc.

(3) The paper also connects illegal conduct with ethical decisions using Rest's four-component model. Using these model students voluntarily developed moral sensitivity $[13,53]$ and moral judgment [54] and took ethical decisions for a sentenced company. Both ethical attributes positively affected moral motivation or willingness to comply with the law [57]. This paper focused on developing moral competences by raising knowledge and skills to increase moral motivation. These factors helped students to take an ethical decision for the illegal cases in the study, always maximizing the benefits for others in society [74]. Moreover, social justice has enhanced the student's willingness or disposition to want and act on using judgment for social improvement [75].

(4) The social framework given for decision-making also raised the students' recognition of different organization's level of fairness [61]. The social dimension helped to increase students' willingness to comply with the law to reach ethical decisions [64,65]. The importance of social regulation on business behavior can increase moral motivation. The study also contributes to other current topics under investigation $[67,68]$.

\section{Conclusions}

Despite numerous studies about ethics methodology in higher education, it is rare to find any cross-sectional studies by multidisciplinary academic staff in business, finance and accounting. A practical methodology helped the academic staff to overcome their lack of knowledge on legal and ethical areas [19-21] by analyzing the court judgments and the violated articles. Ethical decisions were taken and commented on.

Using a perspective-changing method to take socially ethical decisions was very useful for the students. This was done by imagining the decisions other people had taken before and which they could have taken if they had had thought ethically and socially. When using this methodology with students the relationships between latent variables were supported in the proposed hypotheses year after year. Therefore, "ethical education" in $t_{0}$ positively influences $t_{1}$. This means that education in a given period influences the next period. The same goes for the other variable, "willingness to comply with the law". Therefore, teachers must maintain the same quality standards and update their knowledge in order to maintain these results.

Nevertheless, we cannot say that the longitudinal relationship of the constructs means that there will be a continuous increase or decrease in the intensity with which they are related. It is especially striking that the willingness to comply with the law in different periods does not increase with time. This represents a challenge for teachers who should strive to improve their teaching programs to achieve an effect that is increasing and that, in addition, allows carry-over effects to occur each year.

As the results showed, this methodology not only increased the students' ethical knowledge and skills when linking illegal acts with ethical behavior, but also increased their willingness to comply with the law. In order to achieve successfully achieve this goal it is crucial to have a really committed academic research team which works together in the training and teaching activities necessary for the methodological steps of the process.

This teaching methodology for ethical decision-making at universities has great potential not only for shaping future behavior in business and accountancy professionals, but also for improving the civic and professional actions and responsibility of future graduates. This important conclusion confirms that legal and ethical studies can be combined to improve the willingness to comply with the law in higher education. 


\section{Limitations}

The first limitation of the study is the time needed to prepare it, not only to choose appropriate court judgments but also to find a motivated team who understand every aspect of the methodology. In our case, it was not easy due to the multidisciplinary background of the research team.

Secondly, this methodology needs teachers to include the empirical case studies into the academic program in four classes. This means that teachers have to adapt their own programs to these teaching activities.

Thirdly, university students must also be completely involved in the activity. They must understand, from the beginning of the activity, how and why it is carried out at the beginning of the academic course. Otherwise, without the students' agreement, it will not be possible to complete all the teaching and learning activities.

Author Contributions: Rafael Robina Ramirez (R.R.R.) carried out the research and wrote the theoretical part of the paper, Discussion and Conclusion. Pedro R. Palos-Sanchez (P.R.P.-S.) analysed the results of the paper.

Acknowledgments: The research behind the article has been made possible thanks to the collaboration the Innovation Teaching Team who has been involved in the Project along three years.

Conflicts of Interest: The authors declare no conflict of interest.

\section{References}

1. Partnoy, F. Infectious Greed: How Deceit and Risk Corrupted the Financial Markets; Profile Books: London, UK, 2003.

2. Hutchens, A. Changing Big Business: The Globalisation of the Fair Trade Movement; Edward Elgar: Cheltenham, UK, 2009.

3. Kuhlen, L. Cuestiones fundamentales de Compliance y Derecho penal. In Compliance y teoría del Derecho penal; Marcial Pons: Madrid, Spain, 2013; pp. 51-76.

4. Bock, D. Compliance y deberes de vigilancia en la empresa. In Compliance y teoría del Derecho penal; Marcial Pons: Madrid, Spain, 2013; pp. 107-122.

5. Namiri, K.; Stojanovic, N. A model-driven a roach for internal controls compliance in business processes. In Proceedings of the Workshop on Semantic Business Process and Product Lifecycle Management (SBPM), Innsbruck, Austria, 7 June 2007.

6. Nussbaum, M. Educação e Justiça Social [Education and Social Justice]; Edições Pedago: Rmada, Portugal, 2014.

7. Verrax, F. Engineering ethics and post-normal science: A French perspective. Futures 2017, 91, 76-79. [CrossRef]

8. Adkins, N.; Radtke, R.R. Students' and faculty members' perceptions of the importance of business ethics and accounting ethics education: Is there an expectations gap? J. Bus. Ethics 2004, 51, 279-300. [CrossRef]

9. Tormo-Carbó, G.; Seguí-Mas, E.; Oltra, V. Accounting ethics in unfriendly environments: The educational challenge. J. Bus. Ethics 2014. [CrossRef]

10. García, R.; Jover, G.; Escámez, J. Ética Profesional Docente; Síntesis Editorial: Madrid, Spain, 2010.

11. Martin, A.L.A.; Barrera, V.G. Understanding compliance risk across emerging markets. Bus. Compliance 2014, 3, 12-22.

12. Sanger, M.N.; Osguthorpe, R.D. Making sense of a roaches to moral education. J. Moral Educ. 2005, 34, 57-72. [CrossRef]

13. Jones, T.M. Ethical decision making by individuals in organizations: An issue-contingent model. Acad. Manag. Rev. 1991, 16, 366-395. [CrossRef]

14. O'Fallon, M.J.; Butterfield, K.D. A review of the empirical ethical decision-making literature: 1996-2003. J. Bus. Ethics 2005, 59, 375-413. [CrossRef]

15. Tenbrunsel, A.E.; Smith-Crowe, K. Chapter 13: Ethical decision making: Where we've been and where we're going. Acad. Manag. Ann. 2008, 2, 545-607. [CrossRef]

16. Ferguson, J.; Collison, D.; Power, D.; Stevenson, L. Accounting education, socialisation and the ethics of business. Bus. Ethics A Eur. Rev. 2011, 20, 12-29. [CrossRef] 
17. Trevino, L.K.; Weaver, G.R.; Reynolds, S.J. Behaviour al ethics in organizations: A review. J. Manag. 2006, 32, 951-990.

18. Kish-Gephart, J.J.; Harrison, D.A.; Trevino, L.K. Bad a les, bad cases, and bad barrels: Meta-analytic evidence about sources of unethical decisions at work. J. A Lied Psychol. 2010, 95, 1-31. [CrossRef] [PubMed]

19. Argandoña, A. La enseñanza de la ética por el método del caso; Mercado o Comunidad: Salamanca, Spain, 1999.

20. Oddo, A.R. A framework for teaching Business Ethics. J. Bus. Ethics 1997, 16, 293-297. [CrossRef]

21. Colnerud, G.; Granström, K. Respecktförläraryrket: Om läraresyrkesspräkochyrkesetid; DiVA.org:liu-33341; HLS Förlag: Stockholm, Sweden, 2002.

22. Carroll, A.B.; Buchholtz, A.K. Business and Society: Ethics and Stakeholder Management; South-Western Cengage Learning: Mason, $\mathrm{OH}, \mathrm{USA}, 2008$.

23. Rest, J.R. Moral Development: Advances in Research and Theory; Praeger: New York, NY, USA, 1986.

24. Ringle, C.M.; Wende, S.; Becker, J.M. SmartPLS 3. Bönningstedt: SmartPLS, 2015. Available online: http: / / www.smartpls.com (accessed on 21 February 2018).

25. Lupuleac, Z.L.; Lupuleac, S.; Rusu, C. Changing ethical behaviour in times of economic crisis in organizations. Proc. Econ. Financ. 2012, 3, 921-927. [CrossRef]

26. Bjørnskov, C. Economic freedom and economic crises. Eur. J. Polit. Econ. 2016, 45, 11-23. [CrossRef]

27. Pomfret, R. European crises and the Asian economies. J. Asian Econ. 2014, 31, 71-81. [CrossRef]

28. Álvarez, J.A. La banca española ante la actual crisis financiera. Estab. Financ. 2008, 15, 21-38.

29. Sundström, A. Understanding illegality and corruption in forest governance. J. Environ. Manag. 2016, 181, 779-790. [CrossRef] [PubMed]

30. Yau, Y.; Chiu, S.M. Combating building illegality in Hong Kong: A policy Delphi study. Habitat Int. 2015, 49, 349-356. [CrossRef]

31. Krüger, P. Corporate goodness and shareholder wealth. Journal of financial economics, 115, $304-329$. Law Policy 2015, 30, 385-393.

32. Rubasundram, G.A. Perceived "Tone from the Top" During A Fraud Risk Assessment. Proc. Econ. Financ. 2015, 28, 102-106. [CrossRef]

33. Fraser, I.A.; Hatherly, D.J.; Henry, W.M. Illegal acts and the auditor. In Accounting Forum 28; Elsevier: New York, NY, USA, 2004; pp. 99-118.

34. Nielsen, V.L.; Parker, C. To what extent do third parties influence business compliance? J. Law Soc. 2008, 35, 309-340. [CrossRef]

35. Michaelson, C. Compliance and the illusion of ethical progress. J. Bus. Ethics 2006, 66, 241-251. [CrossRef]

36. Hu, H.K.B. The role of corporate compliance programs in determining corporate criminal liability: A suggested approach. Columbia Law Rev. 1996, 96, 1252-1298.

37. Bampton, R.; Cowton, C. Taking stock of accounting ethics scholarship: A review of the journal literature. J. Bus. Ethics 2013, 114, 549-563. [CrossRef]

38. Calderón, R.; Ferrero, I.; Redin, D.M. Ethical codes and corporate responsibility of the most admired companies of the world: Toward a third generation ethics? Bus. Polit. 2012, 14, 1-24. [CrossRef]

39. Eberlein, B.; Matten, D. Business responses to climate change regulation in Canada and Germany: Lessons for MNCs from emerging economies. J. Bus. Ethics 2009, 86, 241-255. [CrossRef]

40. Dolfsma, W. Accounting as applied ethics: Teaching a discipline. J. Bus. Ethics 2006, 63, 209. [CrossRef]

41. Cragg, W. Teaching Business Ethics: The role of ethics in business and in business education. J. Bus. Ethics 1997, 16, 231-245. [CrossRef]

42. McDonald, G.M.; Donleavy, G.D. Objections to the Teaching of Business Ethics. J. Bus. Ethics 1995, 95, 839-853. [CrossRef]

43. Ottewill, R. Business Ethics in the curriculum: Assessing the evidence from U.K. subject review. J. Bus. Ethics 2004, 54, 339-347.

44. Crane, A.; Matten, D. Questioning the domain of the business ethics curriculum. J. Bus. Ethics 2004, 54, 357-369. [CrossRef]

45. Hernández, R.; Silvestri, K.; Alvarez, A. Enseñanza de la ética en la formación gerencial. Revista de Ciencias Sociales. 2007. Available online: http:/ / www.redalyc.org/pdf/280/28011681013.pdf (accessed on 18 January 2018).

46. Felton, E.L.; Sims, R.R. Teaching business ethics: Targeted outputs. J. Bus. Ethics 2005, 60, 377-391. [CrossRef]

47. McDonald, G.M. A case example: Integrating ethics into the academic business curriculum. J. Bus. Ethics 2004, 54, 371-384. [CrossRef] 
48. Ritter, B.A. Can business ethics be trained? A study of the ethical decision-making process in business students. J. Bus. Ethics 2006, 68, 153-164. [CrossRef]

49. Thornberg, R. The lack of professional knowledge in values education. Teach. Teach. Educ. 2008, 24, 1791-1798. [CrossRef]

50. Cornelius, N.; Wallace, J.; Tassabehji, R. An analysis of corporate social responsibility, corporate identity and ethics teaching in business schools. J. Bus. Ethics 2007, 76, 117-135. [CrossRef]

51. Dellaportas, S.; Cooper, B.J.; Leung, P. Measuring moral judgement and the implications of cooperative education and rule-based learning. Account. Financ. 2006, 46, 53-70. [CrossRef]

52. Boni, A.; Lozano, J.F. The generic competences: An opportunity for ethical learning in the European convergence in higher education. Higher Educ. 2007, 54, 819-831. [CrossRef]

53. Hannah, S.T.; Avolio, B.J. Leader character, ethos, and virtue: Individual and collective considerations. Leadersh. Q. 2011, 22, 989-994. [CrossRef]

54. Trevino, L.K. Moral reasoning and business ethics: Implications for research, education, and management. J. Bus. Ethics 1992, 11, 445-459. [CrossRef]

55. Tuning Educational Structures in Europa Project. 2002. Available online: http://tuningacademy.org/wpcontent/uploads/2014/02/TuningEUI_Final-Report_EN.pdf (accessed on 29 March 2017).

56. Schön, D.A. La formación de profesionales reflexivos: Hacia un nuevo diseño de la enseñanza y el aprendizaje en las profesiones/Educatingthereflectivepractitioner (No. 377); Centro de Publicaciones del Ministerio de Educación y Ciencia: Madrid, Spain, 1992.

57. Melé, D. Ethicaleducation in accounting: Integrating rules, values and virtues. J. Bus. Ethics 2005, 57, $97-109$. [CrossRef]

58. Tracy, J.L.; Robins, R.W. Putting the Self into Self-Conscious Emotions: A Theoretical Model. Psychol. Inquiry 2004, 15, 103-125. [CrossRef]

59. Tangney, J.P.; Stuewig, J.; Mashek, D.J. Moral emotions and moral behavior. Annu. Rev. Psychol. 2007, 58, 345-372. [CrossRef] [PubMed]

60. Cohen, T.R.; Wolf, S.T.; Panter, A.T.; Insko, C.A. Introducing the GASP scale: A new measure of guilt and shame proneness. J. Personal. Soc. Psychol. 2011, 100, 947. [CrossRef] [PubMed]

61. Scott, J.T. The Concise Handbook of Management: A Practitioner's Approach; Routledge: New York, NY, USA, 2005.

62. Haidt, J. Wired to be inspired. In The Compassionate Instinct (pp. 86-93); Keltner, D., Marsh, J., Smith, J.A., Eds.; Norton: New York, NY, USA, 2010.

63. Xie, C.; Bagozzi, R.P.; Grønhaug, K. The role of moral emotions and individual differences in consumer responses to corporate green and non-green actions. J. Acad. Mark. Sci. 2015, 43, 333-356. [CrossRef]

64. Stipek, D. The development of pride and shame in toddlers. In Self-Conscious Emotions: The Psychology of Shame, Guilt, Embarrassment, and Pride; Tangney, J.P., Fischer, K.W., Eds.; Guilford: New York, NY, USA, 1995; pp. 237-252.

65. Weiner, B. An attributional theory of achievement motivation and emotion. Psychol. Rev. 1985, 92, 548. [CrossRef] [PubMed]

66. Hart, D.; Matsuba, M.K. The development of pride and moral life. In The Self-Conscious Emotions: Theory and Research; Guilford Press: New York, NY, USA, 2007; pp. 114-133.

67. Gruenewald, T.L.; Dickerson, S.S.; Kemeny, M.E. A social function for self-conscious emotions. In The Self-Conscious Emotions: Theory and Research; Guilford Press: New York, NY, USA, 2007; pp. 68-71.

68. Parker, C.H.; Nielsen, V. The challenge of empirical research on business compliance in regulatory capitalism. Ann. Rev. Law Soc. Sci. 2009, 5, 45-70. [CrossRef]

69. Cawley, M.J., III; Martin, J.E.; Johnson, J.A. A virtues approach to personality. Personal. Individ. Differ. 2000, 28, 997-1013. [CrossRef]

70. Chun, R.; Da Silva, R.; Davies, G.; Roper, S. Corporate Reputation and Competitiveness; Routledge: Abingdonon-Thames, UK, 2005.

71. Westera, W. Competences in education: A confusion of tongues. J. Curric. Stud. 2001, 33, 75-88. [CrossRef]

72. Melé, D. The firm as a "community of persons": A pillar of humanistic business ethos. J. Bus. Ethics 2012, 106, 89-101. [CrossRef]

73. Decety, J.; Cowell, J.M. The complex relation between morality and empathy. Trends Cognit. Sci. 2014, 18, 337-339. [CrossRef] [PubMed]

74. Santos, F.M. A positive theory of social entrepreneurship. J. Bus. Ethics 2012, 111, 335-351. [CrossRef] 
75. Yearley, L.H. Recent Work on Virtue. Relig. Stud. Rev. 1990, 16, 1-10.

76. Schwartz, S.H. Universals in the content and structure of values: Theoretical advances and empirical tests in 20 countries. In Advances in Experimental Social Psychology; Academic Press: Cambridge, MA, USA, 1992; Volume 25, pp. 1-65.

77. Fukukawa, K.; Shafer, W.E.; Lee, G.M. Values and attitudes toward social and environmental accountability: A study of MBA students. J. Bus. Ethics 2007, 71, 381-394. [CrossRef]

78. Feather, N.T.; Woodyatt, L.; McKee, I.R. Predicting support for social action: How values, justice-related variables, discrete emotions, and outcome expectations influence support for the Stolen Generations. Motiv. Emot. 2012, 36, 516-528. [CrossRef]

79. Cheung, W.Y.; Luke, M.A.; Maio, G.R. On attitudes towards humanity and climate change: The effects of humanity esteem and self-transcendence values on environmental concerns. Eur. J. Soc. Psychol. 2014, 44, 496-506. [CrossRef]

80. Kohlberg, L.; Candee, D. The relationship of moral judgment to moral action. Moral. Moral Behav. Moral Dev. 1984, 52, 73.

81. Hair, J.F.; Ringle, C.M.; Sarstedt, M. PLS-SEM: Indexed a silver bullet. J. Market. Theory Pract. 2011, 19, 139-151. [CrossRef]

82. Johnson, M.D.; Herrmann, A.; Huber, F. The evolution of loyalty intentions. J. Mark. 2006, 70, 122-132. [CrossRef]

83. Shea, C.M.; Howell, J.M. Efficacy-performance spirals: An empirical test. J. Manag. 2000, 26, 791-812. [CrossRef]

84. Roemer, E. A tutorial on the use of PLS path modeling in longitudinal studies. Ind. Manag. Data Syst. 2016, 116, 1901-1921. [CrossRef]

85. Sekerka, L.E.; Bagozzi, R.P. Moral courage in the workplace: Moving to and from the desire and decision to act. Bus. Ethics A Eur. Rev. 2007, 16, 132-149. [CrossRef]

86. Carmines, E.G.; Zeller, R.A. Reliability and Validity Assessment; Sage Publications: Thousand Oaks, CA, USA, 1979.

87. Werts, C.E.; Linn, R.L.; Jöreskog, K.G. Intraclass reliability estimates: Testing structural assumptions. Educ. Psychol. Meas. 1974, 34, 25-33. [CrossRef]

88. Henseler, J.; Ringle, C.M.; Sinkovics, R.R. The use of partial least squares path modeling in international marketing. In New Challenges to International Marketing; Emerald Group Publishing Limited: Bingley, UK, 2009.

89. Dijkstra, T.K.; Henseler, J. Consistent partial least squares path modeling. MIS Q. Manag. Inf. Syst. Q. 2015, 39, 297-316. [CrossRef]

90. Fornell, C.; Larcker, D.F. Structural equation models with unobservable variables and measurement error: Algebra and statistics. J. Market. Res. 1981, 18, 382-388. [CrossRef]

91. Henseler, J.; Ringle, C.M.; Sarstedt, M. A new criterion for assessing discriminant validity in variance-based structural equation modeling. J. Acad. Market. Sci. 2015, 43, 115-135. [CrossRef]

92. Gold, A.; Malhotra, A.; Segars, A. Knowledge management: An organizational in Governatori, G., Milosevic, Z., and Sadiq, S. 2006. Compliance checking between business processes and business contracts. In Proceedings of the 10th IEEE International Enterprise Distributed Object Computing Conference (EDOC'06), Seattle, WA, USA, 4-7 September 2001; pp. 221-232.

93. Henseler, J. Bridging Design and Behaviour al Research with Variance-Based Structural Equation Modeling. J. Advert. 2017, 46, 178-192. [CrossRef]

94. Chin, W.W. The partial least squares approach to structural equation modeling. Mod. Methods Bus. Res. 1998, 295, 295-336.

95. Falk, R.F.; Miller, N.B. A Primer for Soft Modelling; University of Akron Press: Akron, OH, USA, 1992.

96. Henseler, J.; Hubona, G.; Ray, P.A. Using PLS path modeling in new technology research: Updated guidelines. Ind. Manag. Data Syst. 2017, 116, 2-20. [CrossRef]

97. Hu, L.T.; Bentler, P.M. Fit indices in covariance structure modeling: Sensitivity to under parameterized model misspecification. Psychol. Methods 1998, 3, 424. [CrossRef]

98. Hu, L.T.; Bentler, P.M. Cutoff criteria for fit indexes in covariance structure analysis: Conventional criteria versus new alternatives. Struct. Equ. Model. 1999, 6, 1-55. [CrossRef] 
99. Stone, M. Cross-validatory choice and assessment of statistical predictions. J. R. Stat. Soc. Ser. B 1974, 36, 111-147.

100. Geisser, S. A predictive approach to the random effect model. Biometrika 1974, 61, 101-107. [CrossRef]

101. Sarstedt, M.; Henseler, J.; Ringle, C.M. Multigroup analysis in partial least squares (PLS) path modeling: Alternative methods and empirical results. In Measurement and Research Methods in International Marketing; Emerald Group Publishing Limited: Bingley, UK, 2011; pp. 195-218. 